\title{
Diastereoselective Decarboxylative Alkynylation of Anomeric Carboxylic Acids Using Cu/Photoredox Dual Catalysis
}

\author{
Mingxiang Zhu ${ }^{[\mathrm{a}]}$ and Samir Messaoudi*[a] \\ ${ }^{[a]}$ Université Paris-Saclay, CNRS, BioCIS, 92290, Châtenay-Malabry, France. \\ KEYWORDS. Anomeric radicals $\bullet$ Copper $\bullet$ dual photoredox catalysis $\bullet$ glycosyl carboxylic acids $\bullet$ Alkynyl $C$-nucleosides
}

ABSTRACT: Alkynyl $C$-nucleosides are of high value for various applications; however, their synthesis remain underexplored. Here we report a simple route towards the synthesis of alkynyl $C$-nucleosides from simple and stable furanosyl carboxylic acids and terminal alkynes under low-cost and non-toxic copper catalysis. The approach that we report here demonstrates the power of $\mathrm{Cu}$ /photoredox dual catalysis to access highly complex glycosides under mild conditions.

$C$-Nucleosides has emerged as a promising class of bioactive glycosides most notably in the fields of virology and cancer therapy. ${ }^{1}$ These derivatives in which the anomeric $\mathrm{C}-\mathrm{N}$ nucleosidic bond is replaced by a $\mathrm{C}-\mathrm{C}$ bond, are considered as glycomimetics of natural nucleosides as they are known to be more resistant towards hydrolysis under biological conditions. ${ }^{2}$ Representative natural and synthetic $C$-nucleosides are disclosed in Figure 1a, including varitriol ${ }^{3}$ and showdomycin ${ }^{4}$ (natural nucleosides), ribavirin analogs ${ }^{5}$ such as pyrazomycin ${ }^{6}$ or $\mathrm{SO}^{7}$ (antitumor agent), and benzamide ribonucleotide (BAR, IMP dehydrogenase inhibitor). Recently, the remdesivir $C$-nucleoside metabolite GS-441524 (Figure 1a) was reported as a potential inhibitor of SARS-CoV-2 by binding to the nsP3 macrodomain of the virus. ${ }^{9}$ Moreover, $C$ nucleosides have been used to study RNA and DNA processing enzymes with the aim to extend the genetic alphabet and designing new therapeutic proteins. ${ }^{10}$

Because of their key role in many biological processes, the development of methods towards an efficient and stereoselective synthesis of $C$-nucleosides is considered to be of great importance. ${ }^{11}$ Various chemical scaffolds such as aromatics, heteroaromatics, alkyls, alkenyls and alkynyls were introduced at the anomeric pentose sugar position. Among all these architectures, alkynylated nucleosides (called also sugar acetylene) are particularly important as they offer a unique opportunity to increase the complexity of the targeted $C$ nucleoside, due to the numerous possible transformations of the $\mathrm{C}-\mathrm{C}$ triple bond (Figure 1b). ${ }^{12}$ For instance, the alkyne function may be subjected to partial or total reduction, hydrometallation $^{13}$ followed by a selective functionalization or $(4+2)$ cycloaddition with azides to produce triazoles ${ }^{14}$ or with dienes $^{15}$ to access to aromatic nucleosides (Figure $\mathbf{1 b}$ ). Besides, $C$-alkynyl nucleosides may be used as partners in a $\mathrm{C}-\mathrm{H}$ activation/annulation process with anilines to afford a variety of substituted $C$-furanosyl indoles. ${ }^{16}$ Otherwise, $C$-ethynyl furanosides are also reported as a promising antibiotic by acting against $\mathrm{Zn}^{2+}$-dependent enzyme $\mathrm{LpxC}^{17}$ (Figure 2a). Despite these possibilities, their use is underdeveloped, and only few methods for their synthesis are reported (Figure 2a). ${ }^{11}$ Among them, the introduction of the alkynyl function at the anomeric position involves the reaction of furanosyl halides or acetates with alkyne iodides mediated by indium. ${ }^{18}$ Organome- tallic alkynes such as alkynyl trifluoroborates ${ }^{19}$ or alkynyltin species $^{20}$ are well known to be good partners in the

(a) Example of natural and bioactive $\boldsymbol{C}$-Nucleosides
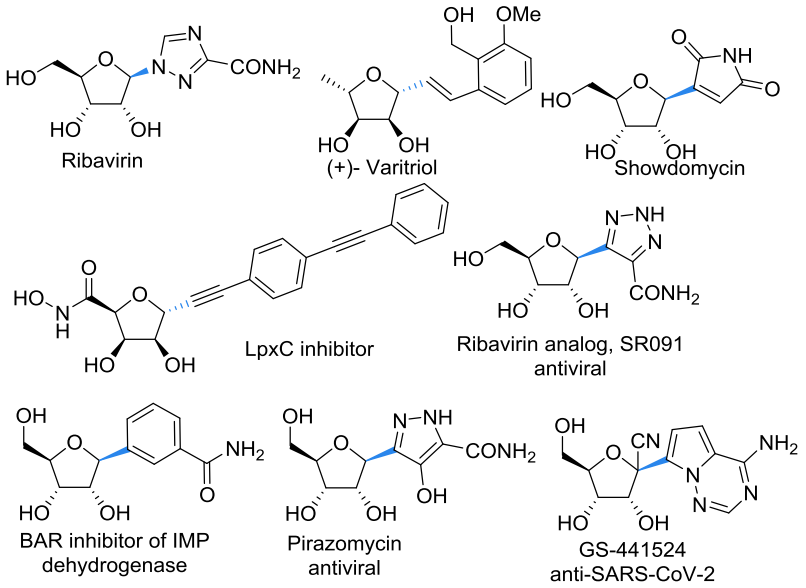

(b) Possible further functionalizations of alkyne $C$-Nucleosides

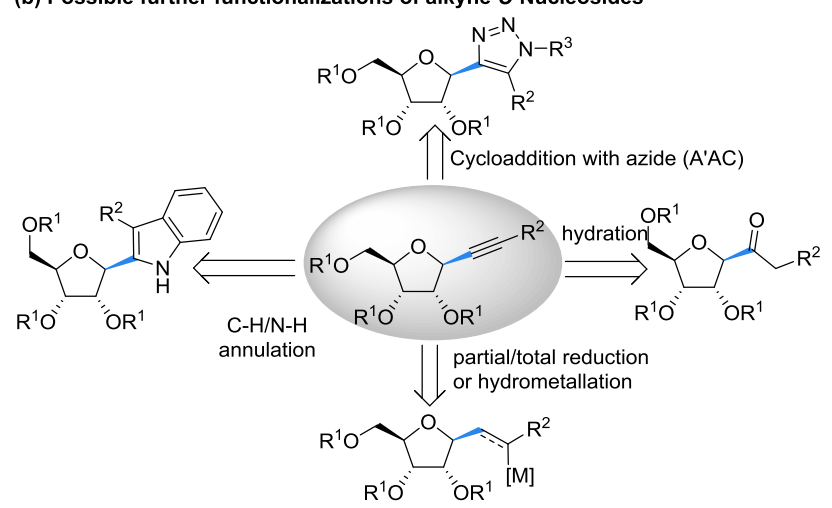

Figure 1. (a) natural and bioactive $\mathrm{C}$-nuleosides, (b) examples of possible transformations of alkynyl C-nuleosides

glycosylation of furanosyl fluorides and bromides in the presence of Lewis acids such as boron trifluoride or zinc chloride. Grignard alkynyl reagents are also used as nucleophiles in the coupling with acetals. ${ }^{21}$ Although their high interest, these methods require the use of harsh conditions (high temperature and excess of the metal in the case of indium coupling) and overstoichiometric amounts of air and moisture sensitive alkynyl organometallics as well as the nature of the used Lewis acidic used. These issues often limit the practicability of the 
(a) classical methods for preparing C-alkynyl glycosides
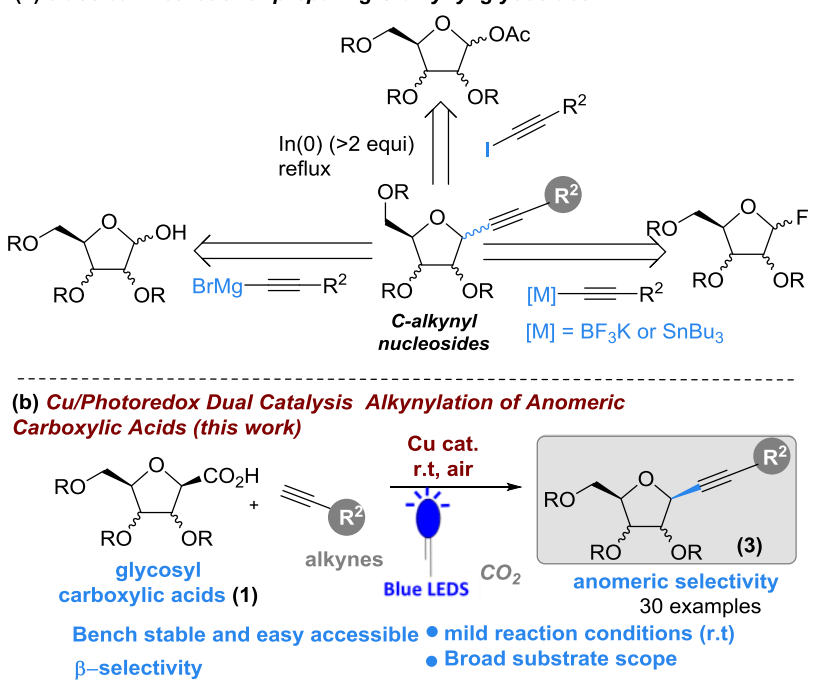

Figure 2. (a) strategies for the synthesis of alkynyl $C$-nuleosides, (b) $\mathrm{Cu}$ /photoredox approach developed herein

scope of substrates. Moreover, a mixture of both anomers is mainly observed in numerous reported methods. Then, developing new, mild and catalytic conditions to access diastereoselectively alkynyl $C$-nucleosides is still one of the highly challenging topics in glycochemistry. In light of the aforementioned challenges, we were intrigued to develop an efficient catalytic method to perform a decarboxylative alkynylation of ribosyl radicals under dual photoredox ${ }^{22}$ catalysis conditions (Figure 2). In this context, anomeric radicals have recently been manipulated in conjunction with $\mathrm{Ni} / \mathrm{Ru}$ or Ir photoredox dual catalysis for the synthesis of alkyl-, (hetero)aryl- and acyl- $C$-glycosides. ${ }^{23}$ Gagnée and co-workers used this approach to generate anomeric radicals from pyranosyl bromides which react with alkenes to produce exclusively alkyl $\alpha$ - $C$-glycopyranosides. ${ }^{24}$ Molander group reported a range of glycosyl-based radicals generated from dihydropyridyl glycoside precursors and coupled with activated carboxylic acids to synthesize non-anomeric $C$-acyl glycosides. $^{25}$ This approach was applied recently to carbohydrate substrates bearing the dihydropyridine (DHP) as an activating anomeric group to prepare $\mathrm{C}$-aryl glycosides, including nucleosides and 2-deoxysugars. ${ }^{26}$ Very recently, 2-deoxyglycosyl boronic acid derivatives were used as radical sources to synthesize a series $\alpha$ - $C$-glycosides mediated by a photoredox/nickel dual catalytic system. ${ }^{27}$ Finally, Wang, Zhang and co-workers ${ }^{28}$ demonstrated for the first time, that ribosyl acids are valuable partners in the photoredox/nickel dual-catalyzed cross-coupling with heteroaryl and vinyl bromides, furnishing various $\beta$-selective heteroaryl- $C$-nucleosides in good yields. Based on this exceptional reactivity of anomeric radicals, we considered them to be well-suited for the development of an alkynylation photoredox cross-coupling process with terminal alkynes. Indeed, pioneer studies demonstrated recently that copper acetylide which could be formed from terminal alkyne and copper salt under mild conditions, were compatible with a photoredox process in the alkynylation of $N$-hydroxy phthalimide esters. ${ }^{29}$ Based on all these observations and our ongoing interests in metal-catalyzed functionalization of sugar motifs, ${ }^{30}$ we propose herein a catalytic method for the decarboxylative alkynylation of ribosyl carboxylic acids with terminal alkynes under copper/photoredox dual catalysis (Figure 2b). This approach which proceeds via anomeric radical intermediate, exhibits many advantages over the conventional methods: $(i)$ the use of bench-stable and easily handled sugar carboxylic acids, (ii) the use of earthabundant and low cost- transition metal copper catalyst, (iii) mild reaction conditions (RT) and (iv) large functional groups tolerance. If successful, this approach would provide not only an excellent complementary pathway to the established alkynylation methods but also immediate access to a reactive platform that can be engaged in numerous postfunctionalization.

To initiate this study, we chose the coupling of tri- $O$ benzylated 1- $\beta$-D-glucofuranose 1a with 4methoxyphenylacytelene $\mathbf{2 a}$ as a model study under various reaction conditions. Representative results from this optimization study are summarized in Table 1 . The reaction of $O$ Benzylated-furanose $1 \mathrm{a}$ ( 1 equiv, $E_{1 / 2 \text { furanose }(\mathrm{OBn}) 3=}=+1.15 \mathrm{~V} v s$ $\mathrm{SCE}$ in $\mathrm{MeCN}$ ) with 2a (3 equiv) was first investigated by using $20 \mathrm{~mol} \%$ of $\mathrm{CuOAc}, 2.5 \mathrm{~mol} \%$ of a commercially available 4 CzIPN photocatalyst $\left(E_{1 / 2\left(\mathrm{PC}^{*} / \mathrm{PC}^{-}\right)}=+1.35 \mathrm{~V} v s \mathrm{SCE}\right.$ in $\mathrm{MeCN}$ ) in the presence of CsOAc (2 equiv) as a base in DMA under blue light emitting diode (LED) irradiation (Table S1, entry 1, ESI). Surprisingly, performing the reaction under argon led to the formation of a mixture of three products: the alkynylated glycoside $3 \mathbf{a}$ in $50 \%$ yield

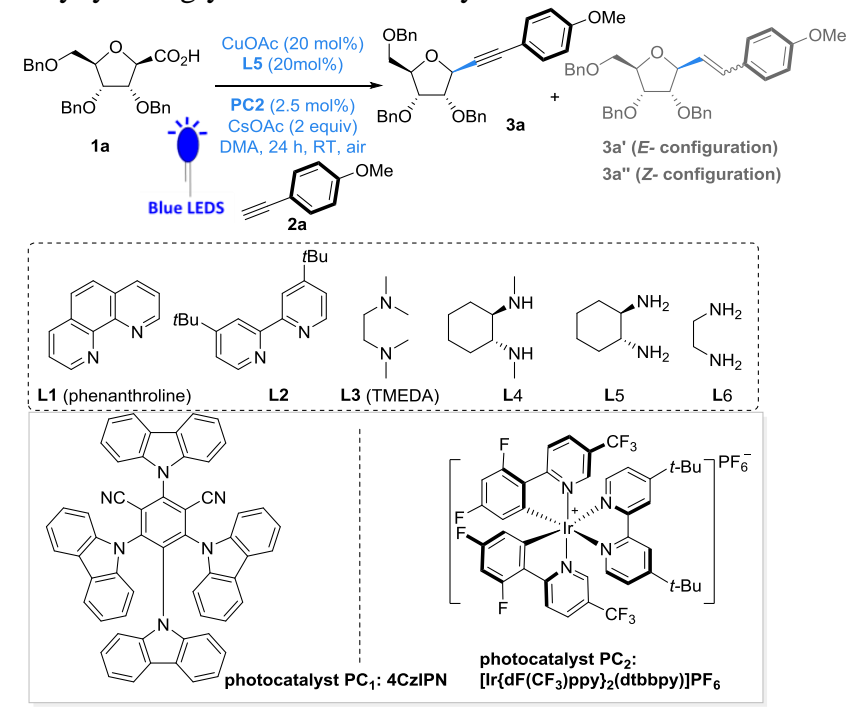

\begin{tabular}{ccc}
\hline Entry & Deviation from the standard conditions & $\begin{array}{c}\text { Yield 3a } \\
(\%)^{b}\end{array}$ \\
\hline 1 & none & 96 \\
2 & PC1 instead PC2 & 78 \\
3 & PC2 1 mol\% & 50 \\
4 & CuOAc 10 mol\% & 61 \\
5 & L1 or L2 or L3 or L4 instead of L5 & traces \\
6 & L6 insteadn of L5 & 48 \\
7 & 1a (1equiv) and 2a (5 equiv) & 40 \\
8 & No photocatalyst PC & 0 \\
9 & No Cu-catalyst & 0 \\
10 & dark & 0 \\
Reactions conditions: $\mathbf{1 a}(0.4$ mmol), 2a $(0.2$ mmol), CsOAc $(0.4$ mmol), \\
DMA (2.0 mL), blue LEDs (4.5 W, irradiation). ${ }^{b}$ Isolated yield.
\end{tabular}

Table 1. Optimization of the coupling reaction of $\mathbf{1 a}$ with $\mathbf{2} \mathbf{a}^{[\mathrm{a]}}$ 
contaminated with $Z$ - and $E$ - alkenyl glycosides 3a' and 3a'. The formation of the undesired alkenyl $C$-nucleosides is in total agreement with the recently reported study of Pericas et $a l$. on the decarboxylative hydroalkylation of alkynes via dual copper-photoredox catalysis. ${ }^{31}$ This first result indicates clearly that under these conditions, two possible pathways are running concomitantly leading to the formation of akynyl (3a) and alkenyl (3a', 3a") products. Importantly, conducting the same reaction under air instead of argon produces exclusively the $\beta$ - $C$-alkynyl nucleoside $3 \mathbf{a}$ in $60 \%$ yield (Table S4, entry 1 , ESI). This second observation demonstrates that the presence of oxygen inhibits the alkenylation pathway in favor of the $\mathrm{C}(\mathrm{sp})-\mathrm{C}\left(\mathrm{sp}^{3}\right)$ bond formation. Nevertheless, a subtle amount of oxygen is necessary for the efficiency of the coupling since running the reaction under pure oxygen did not produce $\mathbf{3 a}$ (Table S4, entry 2, ESI). Although at this stage we don't have any explanation, we can speculate that the high concentration of $\mathrm{O}_{2}$ may induce side reactions involving radical oxygen species. This outcome inspired us to explore this alkynylation reaction under air. Thus, increasing the amount of the 4methoxyphenylacytelene 2a up to 5 equiv furnished 3a in only $37 \%$ yield (Table S5, entry 2, ESI). Fine adjusting the ratio between $\mathbf{1 a} / \mathbf{2 a}$ to $2: 1$ under otherwise the same conditions produces selectively $\mathbf{3 a}$ in an excellent $78 \%$ yield (entry 2, Table 1). Also, reaction with $\operatorname{Ir}\left[\mathrm{dF}\left(\mathrm{CF}_{3}\right) \text { ppy }\right]_{2}(\mathrm{dtbbpy}) \mathrm{PF}_{6}$ photocatalyst $\left(\mathbf{P C} 2, E_{1 / 2\left(\mathrm{PC}^{*} / \mathrm{PC}^{-}\right)}=+1.21 \mathrm{~V}\right.$ v s $\mathrm{SCE}$ in $\left.\mathrm{MeCN}\right)$ instead of $4 \mathrm{CzIPN}$ was more efficient and gave the product $\mathbf{3 a}$ in an excellent $96 \%$ yield (entry 1). Tentative to decrease amounts of the photocatalyst to $1 \mathrm{~mol} \%$ or the copper-catalyst to $10 \mathrm{~mol} \%$ led to low yields $(50 \%$ and $61 \%$ yields respectively, entries 3 and 4). Using other photocatalysts such as $\operatorname{Ir}(\mathrm{p}$ $\mathrm{CF}_{3}$-ppy) $\left.)_{3}, \quad \operatorname{IrMe}(\mathrm{Me}) \mathrm{ppy}_{2}(\mathrm{dtbpy})\right) \mathrm{PF}_{6} \quad$ or tris $_{2-}$ phenylpyridinato- $\mathrm{C}_{2}$-Niridium(III) failed (Table S6, entries 35 , ESI). The influence of the copper $N, N$-ligands was also examined by a screening of different ligands, but only L5 revealed to be efficient since the other ligands were less reactive (L6-8, entries 6-8) or completely inactive (L1-4, entries 25). Negative controlling experiments demonstrated the $\mathrm{Cu}$ catalyst, the Ir-photocatalyst and the light are necessary (entries 8-10) anticipating the cooperative $\mathrm{Cu} / \mathrm{Ir}$ dual photocatalysis mechanism rather than a photoinduced $\mathrm{Cu}$ catalysis one. Of note, the anomeric configuration of $\beta-C$ alkynyl nucleoside 3a was unambiguously assigned by the coupling constant $J_{l, 2}=4.5 \mathrm{~Hz}$ and confirmed for $\mathbf{3 b}\left(J_{l, 2}=4.3\right.$ $\mathrm{Hz}$ ) by comparison with literature NMR data. ${ }^{32}$

Encouraged by these results, we investigated next the scope and limitations of this dual $\mathrm{Cu}$ /photocatalysis process by systematically varying the nature of the alkyne $\mathbf{2}$ and the sugar $\mathbf{1}$. The substrate scope for alkynes was first explored keeping furanosyl acid 1a as the substrate (Scheme 1). Aryl-substituted alkynes bearing electron-withdrawing and electron-donating groups in ortho, meta or para positions (-OMe, $-\mathrm{Cl},-\mathrm{F},-\mathrm{CF}_{3}$, - $\mathrm{COMe}$ and $-\mathrm{CO}_{2} \mathrm{Me}$ ) were successfully reacted under our conditions to afford the corresponding alkynyl $C$-nucleosides (3a-p) in yields up to $96 \%$. In addition, the enyne substrate $\mathbf{2 q}$ was employed successfully in the reaction to produce $\mathbf{3 q}$ in $64 \%$ yield. Moreover, challenging heteroaromatic alkynes could be used in the coupling as compounds $3 \mathbf{r}$ and $3 \mathbf{s}$ obtained in $70 \%$ and $56 \%$ yields, respectively. More interestingly, aliphatic alkynes which are known to be less reactive such as 1-pentyne, 1-hexyne, cyclohexyne, cyclopropyne as well as but-3-yn-1-yl benzene were also successful, furnishing 3t-x in yields ranging from $52 \%$ to $93 \%$. Finally, the substituted 5chloropent-1-yne was employed successfully in this reaction and its $\mathrm{C}\left(s p^{3}\right)-\mathrm{Cl}$ survived during the process $(C$-nucleoside 3y).

Next, we investigated the reactivity of a series of sugar carboxylic acids (Scheme 1). At first, we studied the scope of the coupling of ribofuranoses bearing various common protecting groups. Thus, substrate $\mathbf{1 b}$ bearing benzoyl and acetonide protecting groups underwent an efficient alkynylation to produce $C$-nucleoside $3 \mathbf{z}$ in $54 \%$ yield and in an anticipated $\alpha / \beta$ ratio of $4: 1$ as reported recently. ${ }^{26}$ Otherwise, using the disarming OAc-protecting groups did not provide the desired product 3aa under our optimized conditions.

It is well established that the substituent at the $\mathrm{C} 2$ position of anomeric ribofuranoses plays a critical role in controlling the anomeric configuration. Thus, under our conditions the coupling of 2a with benzyl protected 2-deoxy-D-ribose $\boldsymbol{\beta}$-1d furnished 3ab in $45 \%$ yield and a ratio $\alpha / \beta$ of $6: 1$ in favor of the $\alpha$-anomer. The same reactivity was recently observed on the arylation of furanosyl radicals under photoredox $\mathrm{Ni}$ catalysis. ${ }^{27,28}$ Of note, both $\alpha$ - and $\beta$-anomers were separated through a simple column chromatography. Interestingly, the anomeric configuration does not play any important role in the stereoselectivity of the reaction since running the same reaction starting from the $\boldsymbol{\alpha - 1 d}$ anomer led to the same ratio of $\alpha / \beta$ (7:1). Interestingly, alkynylation of the non-anomeric furanosyl acid 1e was proved to be effective furnishing the reversed alkynyl $C$-nucleoside $\mathbf{3 a c}$ in good yield and excellent diastereoselectivity. Finally, decarboxylative alkynylation of tetrahydrofuran was less efficient under our conditions and provided the desired alkynylated product 3ae in only $10 \%$ yield. Furthermore OBn-protected glucopyranosyl acid $\mathbf{1 h}$ (see ESI, page S7) turned out to be an unsuitable substrate for this reaction as it failed to produce the corresponding alkynylated $C$-pyranoside. This finding demonstrates clearly that generation and reactivities of furanosyl and pyranosyl radicals are different under these photoredox conditions. This may be explained partially, by the significant difference of the reduction potential $\left(E_{1 / 2}\right)$ between the furanosyl and pyranosyl carboxylate salts $\left(E_{1 / 2 \text { furanose }(\mathrm{OBn}) 3}=+1.15 \mathrm{~V}, E_{1 / 2 \text { pyranose }(\mathrm{OBn}) 4}=\right.$ $+1.32 \mathrm{~V}$, respectively) ${ }^{28}$. Thus, we attempted to perform the coupling of 1a and 2a by using a photocatalyst having a higher oxidative potential than PC2 $\left(E_{1 / 2\left(\mathrm{PC}^{*} / \mathrm{PC}^{-}\right)}=+1.21 \mathrm{~V}\right.$ vs $\mathrm{SCE}$ in $\mathrm{MeCN})$ such as $4 \mathrm{CzIPN}\left(E_{1 / 2\left(\mathrm{PC}^{*} / \mathrm{PC}^{-}\right)}=+1.35 \mathrm{~V}\right.$ vs $\mathrm{SCE}$ in $\mathrm{MeCN})$. However, under these conditions, the reaction failed.

Alkynes are highly valuable intermediates in organic synthesis as they can be involved in a wide range of transformations at triple bonds. To further show the synthetic utility of our protocol, we evaluated whether the alkyne function of $\mathbf{3 a}$ could be used as a platform to access more complex C-nucleosides through simple transformations of the $\mathrm{C} \equiv \mathrm{C}$ bond (Scheme 2). To our delight, complete hydrogenation of $\mathbf{3 a}$ afford a pure alkyl $\beta$ - $C$-nucleoside $\mathbf{4 a}$ in an excellent yield. In addition, $\mathbf{3 a}$ was converted to pyridazine $C$-nucleosides $\mathbf{4 b}$ in good yield through inverse demand hetero Diels-Alder reaction with dimethyl 1,2,4,5- tetrazine-3,6-dicarboxylate (Scheme 2). ${ }^{33}$ This is an immediate application to the synthesis of pyrrole $C$ - 
nucleoside analogs of biological interest. ${ }^{34}$ Finally, hydration of the alkyne 3a by PTSA $^{35}$ gave the corresponding ketone $C$ - nucleosides $\mathbf{4} \mathbf{c} / \mathbf{4} \mathbf{c}^{\prime}$ in a 1:3 mixture of both regioisomers $(73 \%$ yield, Scheme 2).

Scheme 1. Scope and limitation of the coupling of furanosyl carboxylic acids 1a-f with alkynes $\mathbf{2}^{a}$
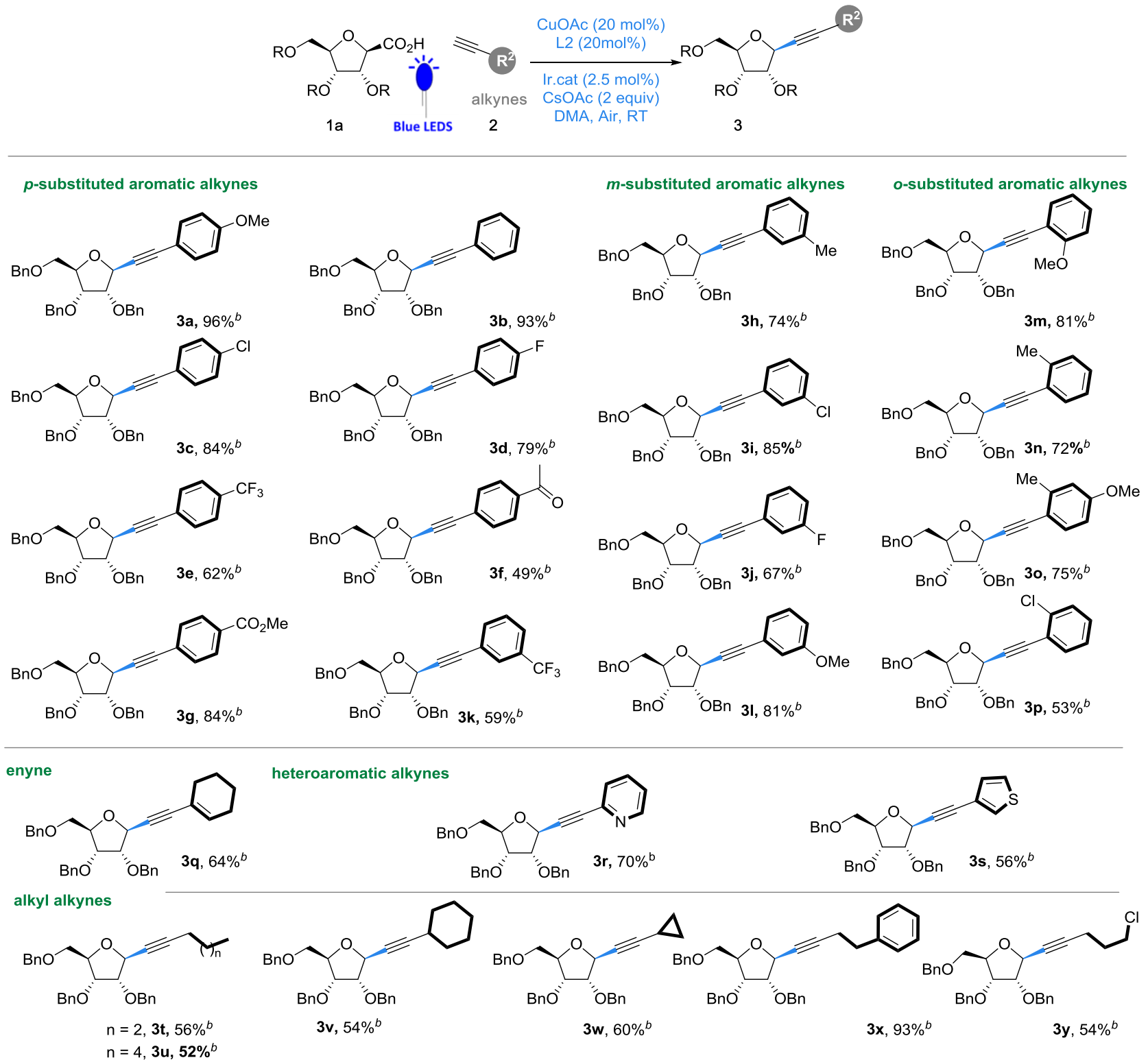


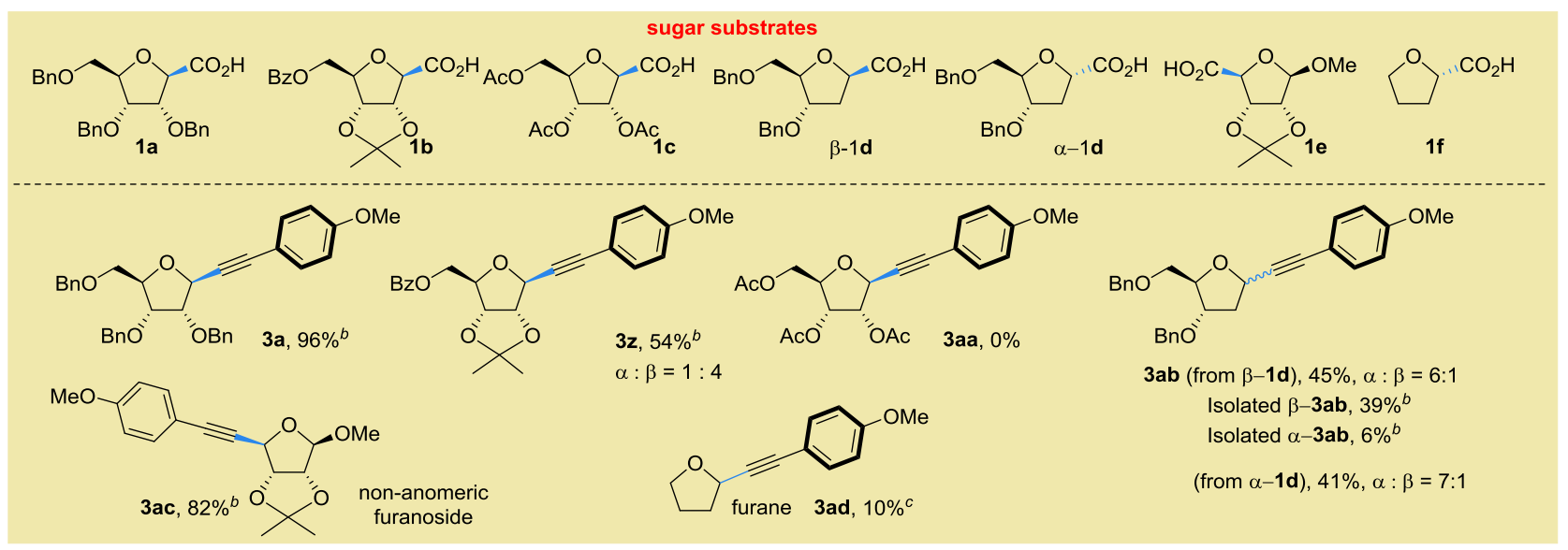

${ }^{a}$ Reaction conditions: 1a $(0.4 \mathrm{mmol}), 2$ (0.2 mmol), CuOAc (20 mol\%), L5 (20 mol\%), PC2 (2.5 mol\%) and CsOAc (0.4 mmol) in DMA $(2.0 \mathrm{~mL})$ under air and blue LEDs $\left(4.5 \mathrm{~W}\right.$, irradiation) for $24 \mathrm{~h} .{ }^{b}$ Isolated yield. ${ }^{c}$ estimated by LCMS.

Scheme 2. Furthers functionalization of the triple bond. ${ }^{a}$

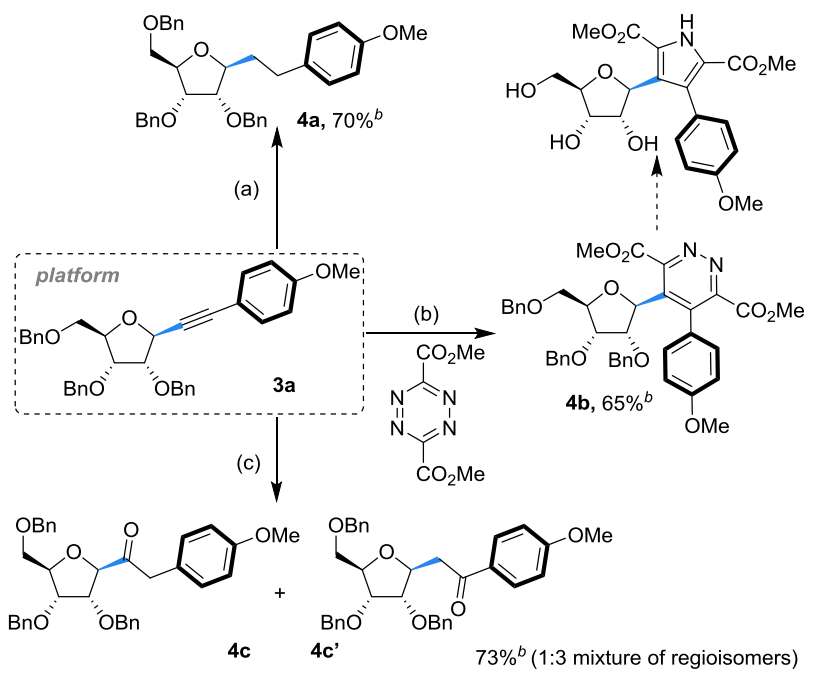

${ }^{a}$ Reactions conditions: (a) 3a $(0.1 \mathrm{mmol})$ and $\mathrm{Pd} / \mathrm{C} 10 \mathrm{wt} \%$ in $\mathrm{MeOH}(0.1 \mathrm{M})$ at $\mathrm{rt}$ for overnight. (b) 3a $(0.2 \mathrm{mmol})$, Dimethyl 1,2,4,5-tetrazine-3,6-dicarboxylate ( $0.3 \mathrm{mmol}, 1.5$ equiv $)$ in toluene $(0.1 \mathrm{M})$, reflux. (c) 3a $(0.1 \mathrm{mmol})$ and PTSA $(0.2$ eq) in $\mathrm{EtOH}(0.4 \mathrm{M})$ at $120{ }^{\circ} \mathrm{C}$, (MW) for $30 \mathrm{~min} .{ }^{b}$ Isolated yield.
Based on recent literature reports, ${ }^{22,28,29}$ a reasonable mechanism is proposed in Scheme 3. The photocatalytic cycle would start by the activation of the iridium catalyst to the excited state Ir* by the means of visible light followed by the oxidation of carboxylic acid (or cesium carboxylate) leading to the formation of the anomeric radical $\mathbf{A}$ and reduced iridium(II) complex. Simultaneously, the reaction of the $\mathrm{Cu}(\mathrm{I})$ catalyst and alkyne 2a in the presence of the base generates the monomeric $\mathrm{Cu}(\mathrm{I})$-acetylene complex II. ${ }^{29,36}$ Then, single electron transfer (SET) of this later led to the Cu(II) complex III. ${ }^{36} \mathrm{At}$ this stage, two pathways may be involved (i) oxidation of the $\mathrm{Cu}(\mathrm{I})$ complex by oxygen as a terminal niddle ${ }^{36 \mathrm{~b}}$ or (ii) by the means of photoexcitation of $[\mathrm{LCu}(\mathrm{I})]$ to $[\mathrm{LCu}(\mathrm{I}) * 3]^{37}$ followed by and electron transfer mechanism. ${ }^{29,36 \mathrm{~b}}$ Later, the anomeric radical $\mathbf{A}$, can be captured by $\mathrm{LCu}(\mathrm{II})$-acetylene III to form the high-valent transient $\mathrm{Cu}$ (III) species IV through the radical relay mechanism. ${ }^{38}$ Reductive elimination would deliver the final $\beta$-alkynyl nucleoside 3a and regenerate the $\mathrm{Cu}(\mathrm{I})$ catalyst for the next catalytic cycle. The final key step cycle would be then the reoxidation of iridium(II) complex by a molecule of dioxygen ${ }^{36 b, 39}$ to generate the ground-state Ir-photocatalyst and close the catalytic cycle. 


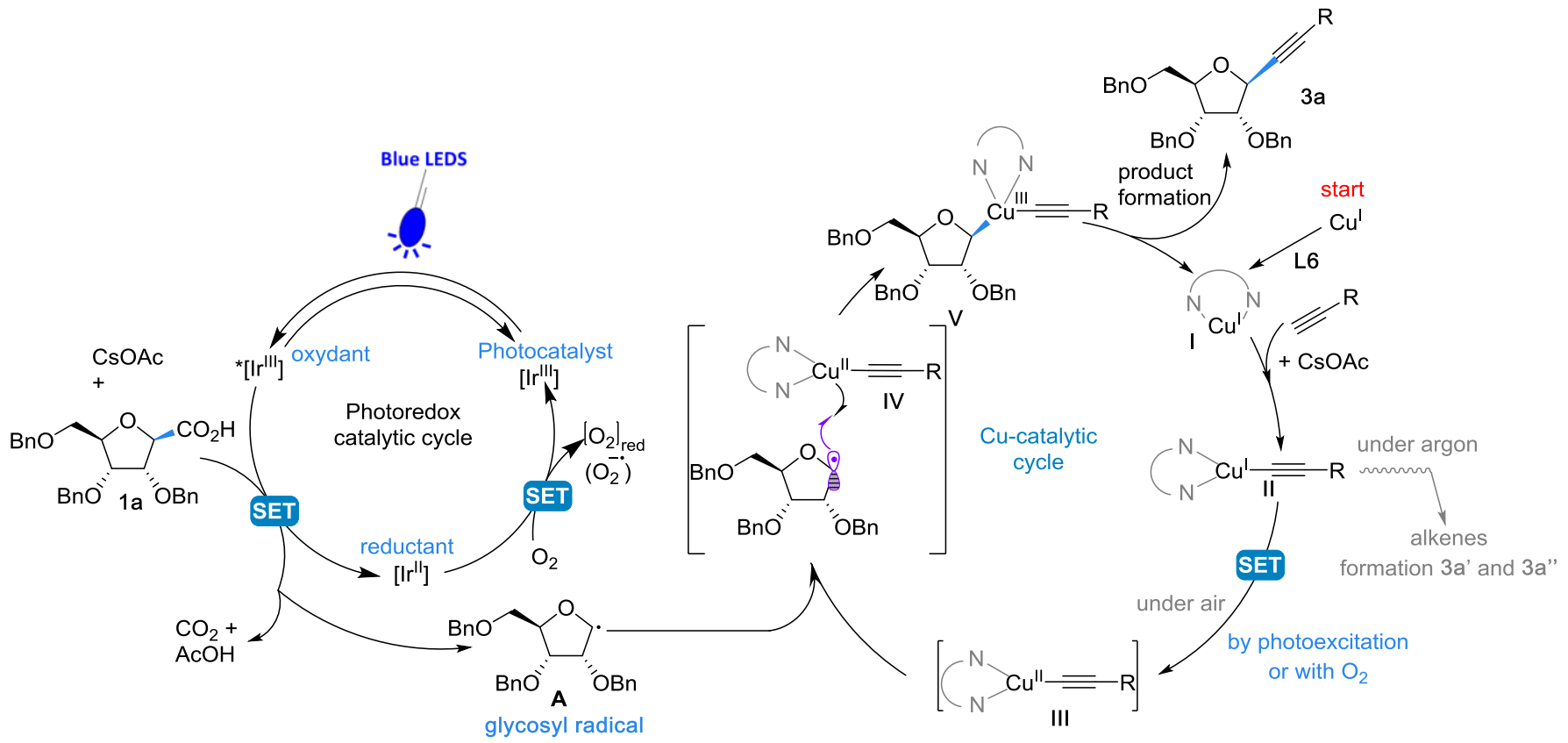

Scheme 3. Proposed mechanism for the dual copper-photoredox catalyzed alkynylation of anomeric radicals

In summary, we described here the first catalytic approach for the alkynylation of anomeric furanosyls with various terminal alkynes via a cooperative photoredox/copper catalysis strategy. This method provides an unprecedented access to alkynyl $C$-nucleosides under mild conditions with high efficiency and diastereoselectivity. Further mechanistic investigations of this reaction are currently underway. We believe that this method not

only opens a new way for catalytic alkynylation of furanosides, but also provides a versatile and convergent approach for the synthesis of complex $C$-nucleosides through further functionalizations of the tripe bond.

\section{ASSOCIATED CONTENT}

\section{Supporting Information}

The Supporting Information is available free of charge on the ACS Publications website.

Full optimization table, NMR spectra of all synthesized compounds and HPLC chromatograms.

\section{AUTHOR INFORMATION}

\section{Corresponding Author}

* samir.messaoudi@univerite-paris-saclay.fr

\section{Author Contributions}

The manuscript was written through contributions of all authors. / All authors have given approval to the final version of the manuscript.

\section{Funding Sources \\ Notes}

The authors declare no competing financial interest

\section{ACKNOWLEDGMENT}

Authors acknowledge support of this project by CNRS, University Paris-Saclay, We also thank the China Scholarship Council for a fellowship (CSC) to Mingxiang Zhu.

\section{ABBREVIATIONS}

\section{REFERENCES}

(1) (a) Jordheim, L. P.; Durantel, D.; Zoulim, F.; Dumontet, C. Advances in the development of nucleoside and nucleotide analogues for cancer and viral diseases. Nat. Rev. Drug Discovery 2013, 12 , 447-464. (b) Coats, S. J.; Garnier-Amblard, E. C.; Amblard, F.; Ehteshami, M.; Amiralaei, S.; Zhang, H.; Zhou, L.; Boucle, S. R. L.; Lu, X.; Bondada, L.; Shelton, J. R;. Li, H.; Liu, P.; Li, C.; Cho, J. H.; Chavre, S. N.; Zhou, S.; Mathew, J.; Schinazi, R. F. Chutes and ladders in hepatitis $\mathrm{C}$ nucleoside drug development. Antiviral Res. 2014, 102, 119-147. (c) Pradere, U.; Garnier-Amblard, E. C.; Coats, S. J.; Amblard, F.; Schinazi, R. F. Synthesis of nucleoside phosphate and phosphonate prodrugs. Chem. Rev. 2014, 114, 9154-9218. (d) DeClercq, E. C-Nucleosides to be revisited: Miniperspective. J. Med. Chem. 2016, 59, 2301-2311. (e) Draffan, A. G.; Frey, B.; Pool, B.; Gannon, C.; Tyndall, E. M.; Lilly, M.; Francom, P.; Hufton, R.; Halim, R.; Jahangiri, S.; Bond, S.; Nguyen, V. T. T.; Jeynes, T. P.; Wirth, V.; Luttick, A.; Tilmanis, D.;. Thomas, J. D; Pryor, M.; Porter, K.; Morton, C. J.; Lin, B.; Duan, J.; Kukolj, G.; Simoneau, B.; McKercher, G.; Lagacé, L.; Amad, M.; Bethell, R. C.; Tucker, S. P. Discovery and Synthesis of C-Nucleosides as Potential New AntiHCV Agents. ACS Med. Chem. Lett. 2014, 5, 679-684. (f) Wang, G.; Wan, J.; Hu, Y.; Wu, X.; Prhavc, M.; Dyatkina, N.; Rajwanshi, V. K.; Smith, D. B.; Jekle, A.; Kinkade, A.; Symons, J. A.; Jin, Z.; Deval, J.; Zhang, Q.; Tam, Y.; Chanda, S.; Blattand, L.; Beigelman, L. Synthesis and Anti-Influenza Activity of Pyridine, Pyridazine, and Pyrimidine C-Nucleosides as Favipiravir (T-705) Analogues. J. Med. Chem. 2016, 59, 4611-4624. (g) Franchetti, P.; Cappellacci, L.; Grifantini, M.; Barzi, A.; Nocentini, G.; Yang, H.; O’Connor, A.; Jayaram, H. N.; Carrell, C.; Goldstein, B. M. Furanfurin and Thiophenfurin: Two Novel Tiazofurin Analogs. Synthesis, Structure, Antitumor Activity, and Interactions with Inosine Monophosphate Dehydrogenase. J. Med. Chem. 1995, 38, 3829-3837. (h) Krohn, K.; Heinsand, H.; Wielckens, K. Synthesis and cytotoxic activity of Cglycosidic nicotinamide riboside analogs. J. Med. Chem. 1992, 35, 
511-517. (i) Feldman, A. W.; Romesberg, F. E.; Expansion of the Genetic Alphabet: A Chemist's Approach to Synthetic Biology. Acc. Chem. Res., 2018, 51, 394-403. (j) Subadolnik, R. J. Nucleoside Antibiotics, Wiley Interscience, NewYork, 1970. (k) Marquez, V. E.; Lim, M. I.; Carbocyclic Nueleosides. Med. Res. Rev. 1986, 6, 1-40. (1) Levy, D. E.; Tang, C. The Chemistry of C-Glycosides, Pergamon, Oxford, 1995. (m) Ritchie, G. E.; Moffatt, B. E.; Sim, R. B.; Morgan, B. P.; Dwek, R. A.; Rudd, P. M. Glycosylation and the Complement System. Chem. Rev. 2002, 102, 305-320. (n) Hanessian, S.; Lou, B. Synthesis of Glycopeptides Containing Carbohydrate and Peptide Recognition Motifs. Chem. Rev. 2000, 100, 4495-4538.

(2) (a) Dwek, R. A. Glycobiology: Toward Understanding the Function of Sugars. Chem. Rev. 1996, 96, 683-720. (b) Nicotra, F. Synthesis of C-glycosides of biological interest. Top. Curr. Chem. 1997, 187, 55-83. (b) Weatherman, R. V.; Mortell, K. H.; Chervenak, M.; Kiessling, L. L.; Toone, E. J. Specificity of C-Glycoside Complexation by Mannose/Glucose Specific Lectins. Biochemistry 1996, 35, 3619-3624. (c) Davis, F. F.; Allen, F. W. Utilization of purines and their derivatives by Gaffkya Homari. J. Biol. Chem. 1957, 227, 807-810. (d) Michelson, A. M.; Cohn, W. E. Cyclopseudouridine and the configuration of pseudouridine. Biochemistry 1962, 1, 490-495. e) Cortese, R.; Kammen, H. O.; Spengler, S. J.; Ames, B. N. Biosynthesis of Pseudouridine in Transfer Ribonucleic Acid. J. Biol. Chem. 1974, 249, 1103-1108. (f) Daves, G. D.; Cheng, C. C. The Chemistry and Biochemistry of C-Nucleosides. Prog. Med. Chem. 1976, 13, 303-349. (g) Hacksell, U.; Daves, G. D. The Chemistry and Biochemistry of C-Nucleosides and C-Arylglycosides. Prog. Med. Chem. 1985, 22, 1-65. (h) Samuelsson, T.; Boren, T.; Johansen, T. I.; Lustig, F. Properties of a transfer RNA lacking modified nucleosides. J. Biol. Chem. 1988, 263, 13692-13699. (i) Townsend L. B. Chemistry of Nucleosides and Nucleotides; 1994; Vol. 3.

(3) Kumar, V.; Shaw, A. K. First Total Synthesis of (+)-Varitriol. J. Org. Chem. 2008, 73, 7526-7531.

(4) (a) Roy-Burman, S.; Roy-Burman, P.; Visser, D. W Showdomycin, A New Nucleoside Antibiotic, Cancer Res. 1968, 28, 1605-1610. (b) Palmu, K.; Rosenqvist, P.; Thapa, K.; Ilina, Y.; Siitonen, V.; Baral, B.; Mäkinen, J.; Belogurov, G.; Virta, P.; Niemi, J.; Metsä-Ketelä, M. Discovery of the Showdomycin Gene Cluster from Streptomyces showdoensis ATCC 15227 Yields Insight into the Biosynthetic Logic of C-Nucleoside Antibiotics. ACS Chem Biol. 2017, 16, 1472-1477. (c) Böttcher, T.; Sieber, S. A. Showdomycin as a Versatile Chemical Tool for the Detection of PathogenesisAssociated Enzymes in Bacteria. J. Am. Chem. Soc. 2010, 132, 6964 6972.

(5) (a) Witkowski, J. T.; Robins, R. K.; Sidwell, R. W.; Simon, L. N. Design, Synthesis, and Broad Spectrum Antiviral Activity of 1- $\beta-\mathrm{D}$ Ribofuranosyl-1, 2, 4-triazole-3-carboxamidef and Related Nucleosides. J. Med. Chem. 1972, 15, 1150-1154. (b) Sidwell, R. W.; Huffman, J. H.; Khare, G. P.; Allen, L. B.; Witkowski, J. T.; Robins, R. K. Broad-Spectrum Antiviral Activity of Virazole: 1-f8- DRibofuranosyl- 1, 2, 4-triazole-3-carboxamide. Science 1972, 177, 705-706. (c) Choo, Q. L.; Kuo, G.; Weiner, A. J.; Overby, L. R.; Bradley, D. W.; Houghton, M. Isolation of a cDNA clone derived from a blood-borne non-A, non-B viral hepatitis genome. Science 1989, 244, 359-362.

(6) (a) Sweeney, M. J.; Davis, F. A.; Gutowski, G. E.; Marnili, R. L.; Hoffman, D. H.; Poore, G. A. Experimental Antitumor Activity of Pyrazomycin. Cancer Res. 1973, 33, 2619-2623. (b) Gutowski, G. E.; Chaney, M. O.; Jones, N. D.; Hamill, R. L.; Davis, F. A.; Miller, R. D. Pyrazomycin B: Isolation and characterization of an $\alpha$-Cnucleoside antibiotic related to pyrazomycin. Biochem. and Biophys. Res. Commun. 1973, 51, 312--317.

(7) (a) Sabat, N.; Migianu-Griffoni, E.; Tudela, T.; Lecouvey, M.; Kellouche, S.; Carreiras, F.; Gallier, F.; Uziel, J.; Lubin-Germain, N. Synthesis and antitumor activities investigation of a C-nucleoside analogue of ribavirin. Eur. J. Med. Chem. 2020, 188, 112009-11016. (b) Solarte, C.; Dos Santos, M.; Gonzalez, S.; Miranda, L. S. M.; Guillot, R.; Ferry, A.; Gallier, F.; Uziel, J.; Lubin-Germain, N. Synthesis of C-Ribosyl-1, 2, 3-triazolyl Carboxamides. Synthesis 2017 , 49, 1993-2002. (c) Youcef, R.; Santos, M.; Roussel, S.; Baltaze, J.; Lubin-Germain, N.; Uziel, J. Huisgen Cycloaddition Reaction of CAlkynyl Ribosides under Micellar Catalysis: Synthesis of Ribavirin Analogues. J. Org. Chem. 2009, 74, 4318-4323.

(8) (a) Krohn, K.; Heins, H.; Wielckens, K. Synthesis and Cytotoxic Activity of C-Glycosidic Nicotinamide Riboside Analogues. J. Med. Chem. 1992, 35, 511-517. (b) Jayaram, H. N.; Gharehbaghi, K.; Jayaram, N. H.; Rieser, J.; Krohn, K.; Paull, K. D. Cytotoxicity of a new IMP dehydrogenase inhibitor, benzamide riboside, to human myelogenous leukemia K562 cells. Biochem. Biophys. Res. Commun. 1992, 186, 1600-1606. (c) Gharehbaghi, K.; Paull, K. D.; Kelley, J. A.; Barchi, J. J.; Marquez, V. E.; Cooney, D. A.; Monks, A.; Scudiero, D.; Krohn, K.; Jayaram, H. N. Cytotoxicity and characterization of an active metabolite of benzamide riboside, a novel inhibitor of IMP dehydrogenase. Int. J. Cancer 1994, 56, 892-899. (d) Saunders, P. P.; Arimilli, S.; Krohn, K.; Muhs, M. A.; Alvarez, E.; Survelyer, R. Metabolism and action of benzamide riboside in Chinese hamster ovary cells. AntiCancer Drugs 1996, 7, 93-99. (e) Grush, M.; Rosenberger, G.; Fuhrman, G.; Braun, K.; Titscher, B.; Szekeres, T.; Fritzer-Szekeres, M.; Oberhuber, G.; Krohn, K.; Hengstschlaeger, M.; Krupitza, G.; Jayaram, H. N. Benzamide riboside induces apoptosis independent of $\mathrm{Cdc} 25 \mathrm{~A}$ expression in human ovarian carcinoma N.1 cells. Cell Death Differ. 1999, 8, 736744. (f) Krohn, K.; Dorner, H.; Zukowski, M. Chemical Synthesis of Benzamide Riboside. Curr. Med. Chem. 2002, 9, 727-731. (g) Gharehbaghi, K.; Grunberger, W.; Jayaram, H. N. Studies on the Mechanism of Action of Benzamide Riboside: A Novel Inhibitor of IMP Dehydrogenase. Curr. Med. Chem. 2002, 9, 743-748.

(9) Ni, X.; Schröder, M.; Olieric, V.; Sharpe, M. E.; HernandezOlmos, V.; Proschak, E.; Merk, D.; Knapp, S.; Chaikuad, A. Structural Insights into Plasticity and Discovery of Remdesivir Metabolite GS-441524 Binding in SARS-CoV-2 Macrodomain. ACS Med. Chem. Lett. 2021, 12, 603-609.

(10) (a) Dhami, K.; Malyshev, D. A.; Ordoukhanian, P.; Kubelka, T.; Hocek, M.; Romesberg, F. E. Systematic exploration of a class of hydrophobic unnatural base pairs yields multiple new candidates for the expansion of the genetic alphabet. Nucleic Acids Res. 2014, 42, 10235-10244. (b) Feldman, A. W.; Dien, V. T.; Karadeema, R. J.; Fischer, E. C.; You, Y.; Anderson, B. A.; Krishnamurthy, R.; Chen, J. S.; Li, L.; Romesberg, F. E. Optimization of Replication, Transcription, and Translation in a Semi-Synthetic Organism. J. Am. Chem. Soc. 2019, 141, 10644-10653. (c) Lavergne, T.; Degardin, M.; Malyshev, D. A.; Quach, H. T.; Dhami, K.; Ordoukhanian, P.; Romesberg, F. E. Expanding the Scope of Replicable Unnatural DNA: Stepwise Optimization of a Predominantly Hydrophobic Base Pair. J. Am. Chem. Soc. 2013, 135, 5408-5419. (d) Malyshev, D. A.; Dhami, K.; Lavergne, T.; Chen, T.; Dai, N.; Foster, J. M.; Corrêa, I. R.; Romesberg, F. E. A semi-synthetic organism with an expanded genetic alphabet. Nature 2014, 509, 385-388. (e) Guo, J.; Wang, S.; Dai, N.; Teo, Y. N.; Kool, E. T. Multispectral labeling of antibodies with polyfluorophores on a DNA backbone and application in cellular imaging. Proc. Natl. Acad. Sci. 2011, 108, 3493-3498.

(11) (a) Temburnikar, K.; Seley-Radtke, K. L. Recent advances in synthetic approaches for medicinal chemistry of C-nucleosides. Beilstein J. Org. Chem. 2018, 14, 772-785. (b) Tatina, M. B.; Hussain, A.; Dhas, A. K.; Mukherjee, D. Advances in C-alkynylation of sugars and its application in organic synthesis. RSC Adv. 2016, 6 , 75960-75972.

(12) Selected review: (a) Song, G.; Fen, W.; Li, X. C-C, C-O and C-N bond formation via rhodium(III)-catalyzed oxidative $\mathrm{C}-\mathrm{H}$ activation. Chem. Soc. Rev. 2012, 41, 3651-3678. (b) Song, X.; Qiu, Y.; Liu, X.; 
Liang, Y. Recent advances in the tandem reaction of azides with alkynes or alkynols. Org. Biomol. Chem. 2016, 14, 11317-11331. (c) Severin, R.; Doye, S. The catalytic hydroamination of alkynes. Chem. Soc. Rev. 2007, 36, 1407-1420. (d) Pohlki, F.; Doye, S. The catalytic hydroamination of alkynes. Chem. Soc. Rev. 2003, 32, 104-114. (e) Alonso, F.; Beletskaya, I. P.; Yus, M. Transition-Metal-Catalyzed Addition of Heteroatom-Hydrogen Bonds to Alkynes. Chem. Rev. 2004, 104, 3079-3160. (e) Müller, T. E.; Beller, M. Metal-Initiated Amination of Alkenes and Alkynes. Chem. Rev. 1998, 98, 675-704.

(13) Alami, M.; Hamze, A.; Provot, O. Hydrostannation of Alkynes. ACS Catalysis 2019, 9, 3437-3466.

(14) Ma, J.; Ding, S. Transition Metal-Catalyzed Cycloaddition of Azides with Internal Alkynes. Asian J. Org. Chem. 2020, 9, 18721888 .

(15) (a) Ackermann, L. Carboxylate-Assisted Ruthenium-Catalyzed Alkyne Annulations by $\mathrm{C}-\mathrm{H} / \mathrm{Het}-\mathrm{H}$ Bond Functionalizations. Acc. Chem. Res. 2014, 47, 281-295. (b) Guo, T. L.; Huang, F.; Yu, L. K.; $\mathrm{Yu}, \mathrm{Z}$. K. Indole synthesis through transition metal-catalyzed C-H activation. Tetrahedron Lett. 2015, 56, 296-302. (c) Kumar, I.; Kumar, R.; Sharma, U. Recent Advances in the Regioselective Synthesis of Indoles via C-H Activation/Functionalization. Synthesis 2018, 50, 2655-2677. (d) Mancuso, R.; Dalpozzo, R. Recent Progress in the Transition Metal Catalyzed Synthesis of Indoles. Catalysts 2018, 8, 458-464.

(16) Hilt, G.; Danz, M. Regioselective Cobalt-Catalyzed Diels-Alder Reaction towards 1, 3-Disubstituted and 1, 2, 3-Trisubstituted Benzene Derivatives. Synthesis 2008, 14, 2257-2263.

(17) Jana, K. S.; Löppenberg, M.; Daniliuc, C. G.; Holl, R. Synthesis and biological evaluation of C-ethynyl furanosides as LpxC inhibitors. Tetrahedron 2015, 71, 956-966.

(18) Germain, N. L.; Baltaze, J. P.; Coste, A.; Hallonet, A.; Lauréano, H.; Legrave, G.; Uziel, J.; Auge, Direct C-Glycosylation by IndiumMediated Alkynylation on Sugar Anomeric Position. J. Org. Lett. 2008, 10, 725-728.

(19) (a) Zeng, J.; Vedachalam, S.; Xiang S.; Liu, X.-W. Synthesis of Pillar[5]arene Dimers and Their Cooperative Binding toward Some Neutral Guests. Org. Lett. 2011, 13, 42-45. (b) Asano, N. Glycosidase inhibitors: update and perspectives on practical use. Glycobiology 2003, 13, 93R-104R. (c) Asano, N.; Nash, R. J.; Molyneux, R. J.; Fleet, G. W. J. Sugar-mimic glycosidase inhibitors: natural occurrence, biological activity and prospects for therapeutic application. Tetrahedron: Asymmetry 2000, 11, 1645-1680.

(20) Zhai, D.; Zhai, W.; Williams, R. M. Alkynylation of Mixed Acetals with Organotin Acetylides. J. Am. Chem Soc. 1988, 110, 2501-2505.

[21] Buchanan, J.G.; Edgar, A.R.; Power, M. J. C-nucleoside studies. Part I. Synthesis of [2, 3, 5-tri-O-benzyl- $\alpha$ (and $\beta$ )-Dribofuranosyl]ethyne. J. Chem. Soc. Perkin Trans. I 1974, 1943-1949.

(22) (a) Vaillant, F. L.; Waser, J. Alkynylation of radicals: spotlight on the "Third Way" to transfer triple bonds. Chem. Sci. 2019, 10, 8909-8923. (b) Vaillant, F. L.; Courant, T.; Waser, J. RoomTemperature Decarboxylative Alkynylation of Carboxylic Acids Using Photoredox Catalysis and EBX Reagents. Angew. Chem. Int. Ed. 2015, 54, 11200-11356.

(23) (a) Xu, L.; Fana, N.; Hu, X. Recent development in the synthesis of C-glycosides involving glycosyl radicals. Org. Biomol. Chem. 2020, 18, 5095-5109. (b) Ghouilem, J.; Robichon, M. D.; Bideau, F. L.; Ferry, A.; Messaoudi, S. Emerging Organometallic Methods for the Synthesis of C-Branched (Hetero)aryl, Alkenyl, and Alkyl Glycosides: C-H Functionalization and Dual Photoredox Approaches. Chem. Eur. J. 2021, 27, 491-511.
(24) (a) Andrews, R. S.; Becker J. J.; Gagné, M. R. Intermolecular Addition of Glycosyl Halides to Alkenes Mediated by Visible Light. Angew. Chem. Int. Ed. 2010, 49, 7274-7276. (b) Andrews, R. S.; Becker, J. J.; Gagné, M. R. A photoflow reactor for the continuous photoredox-mediated synthesis of C-glycoamino acids and Cglycolipids. Angew. Chem. Int. Ed. 2012, 51, 4140-4143.

(25) Dumoulin, A.; Matsui, J. K.; Gutiérrez- Bonet, A.; Molander, G. A. Synthesis of Non-Classical Arylated C-Saccharides through Nickel/Photoredox Dual Catalysis. Angew. Chem. Int. Ed. 2018, 57, 6614 6728 .

(26) Wei, Y.; Benzvi, B.; Diao, T. Diastereoselective Synthesis of Aryl C-Glycosides from Glycosyl Esters via C-O Bond Homolysis. Angew. Chem. Int. Ed. 2021, 60, 9433-9438.

(27) Takeda, D.; Yoritate, M.; Yasutomi, H.; Chiba, S.; Moriyama, T.; Yokoo, A.; Usui, K.; Hirai, G. $\beta$-Glycosyl Trifluoroborates as Precursors for Direct $\alpha$-C-Glycosylation: Synthesis of 2-Deoxy- $\alpha-\mathrm{C}$ glycosides. Org. Lett. 2021, 23, 1940-1944.

(28) Ma, Y.; Liu, S.; Xi, Y.; Li, H.; Yang, K.; Cheng, Z.; Wang, W.; Zhang, Y. Highly stereoselective synthesis of aryl/heteroaryl-Cnucleosides via the merger of photoredox and nickel catalysis. Chem. Coтmun. 2019, 55, 14657-14660.

(29) (a) Xia, H.-D.; Li, Z.; Gu, Q.; Dong, X.-Y.; Fang, J.; Du, X.; Wang, L.; Liu, X. Photoinduced Copper-Catalyzed Asymmetric Decarboxylative Alkynylation with Terminal Alkynes. Angew. Chem. Int. Ed. 2020, 59, 16926-16932; (b) Mao, Y.; Zhao, W.. Lu, S.; Yu, L.; Wang, Y.; Liang, Y.; Ni, S.; Pan, Y. Copper-catalysed photoinduced decarboxylative alkynylation: a combined experimental and computational study, Chem. Sci., 2020, 11, 4939-4947

(30) Selected articles: (a) Ghouilem, J.; Tran, C.; Grimblat, N.; Retailleau, P.; Alami, M.; Gandon, V.; Messaoudi, S. Diastereoselective PdCatalyzed Anomeric $\mathrm{C}\left(\mathrm{sp}^{3}\right)$-H Activation: Synthesis of $\alpha$-(Hetero)aryl C-Glycosides. ACS Catal. 2021, 11, 1818-1826. (b) Zhu, M.; Alami, M.; Messaoudi, S. Electrochemical nickel-catalyzed Migita crosscoupling of 1-thiosugars with aryl, alkenyl and alkynyl bromides. Chem. Chomm. 2020, 56, 4464-4467. (c) Ghouillem, J.; Franco, R.; Retailleau, P.; Alami, M.; Gandon, V.; Messaoudi, S. Regio- and diastereoselective Pd-catalyzed synthesis of C2-aryl glycosides. Chem.Commun. 2020, 56, 7175-7178. (d) Zhu, M.; Dagousset, G.; Alami, M.; Magnier, E.; Messaoudi, S. Ni/Photoredox-DualCatalyzed Functionalization of 1-Thiosugars. Org. Lett. 2019, 21, 5132-5137. (e) Montoir, D.; Amoura, M.; Ababsa, Z. E. -A.; Vishwanath, T. M.; Yen-Pon, E.; Robert, V.; Beltramo, M.; Piller, V.; Alami, M.; Aucagne, A.; Messaoudi, S. Synthesis of arylthioglycopeptides through chemoselective Pd-mediated conjugation. Chem. Sci. 2018, 9, 8753-8759. (f) Probst, N.; Grelier, G.; Dahaoui, S.; Alami, M.; Gandon, V.; Messaoudi, S. Palladium(II)-Catalyzed Diastereoselective 2, 3-Trans $\mathrm{C}\left(\mathrm{sp}^{3}\right)-\mathrm{H}$ Arylation of Glycosides. ACS. Catal. 2018, 8, 7781-7786. (g) Probst, N.; Grelier, G.; Ghermani, N.; Gandon, V.; Alami, M.; Messaoudi, S. Intramolecular Pd-Catalyzed Anomeric $\mathrm{C}\left(\mathrm{sp}^{3}\right)-\mathrm{H}$ Activation of Glycosyl Carboxamides. Org. Lett. 2017, 19, 5038-5041. (h) Bruneau, A.; Roche, M.; Hamze, A.; Brion, J. D.; Alami, M.; Messaoudi, S. Stereoretentive Palladium-Catalyzed Arylation, Alkenylation, and Alkynylation of 1-Thiosugars and Thiols Using Aminobiphenyl Palladacycle Precatalyst at Room Temperature. Chem. Eur. J, 2015, 21, 8375-8379.

(31) Mastandrea, M. M.; Cañellas, S.; Caldentey, X.; Pericàs, M. A. Decarboxylative Hydroalkylation of Alkynes via Dual CopperPhotoredox Catalysis. ACS Catal. 2020, 10, 6402-6408.

(32) (a) Zhai, D.; Zhai, W.; Williams, R. M. Alkynylation of Mixed Acetals with Organotin Acetylides, J. Am. Chem. Soc. 1988, 110 2501-2505; (b) Naud, S.; Pipelier, M.; Viault, G.; Adjou, A.; Huet, F.; Legoupy, S.; Aubertin, A.; Evain, M.; Dubreuil, D. Synthesis of Polyhydroxylated Pyrano-Pyrrole Derivatives from Carbohydrate 
Precursors, Eur. J. Org. Chem., 2007, 20, 3296-3310; (c) Naud, S. Pipelier, M.; Chaumette, C.; Viault, G.; Huet, F.; Legoupy, S.; Dubreuil, D. Synthesis of Novel Polyhydroxylated Tetrahydropyranopyrroles, Synlett, 2007, 3, 403-406.

(33) Joshi, U.; Josse, S.; Pipelier, M.; Chevallier, F.; Pradère, J. -P.; Hazard, R.; Legoupy, S.; Huet, F.; Dubreuil, D. Novel pyrrole Cnucleosides by nitrogen extrusion from pyridazine C-nucleosides. Tetrahedron Lett. 2004, 45, 1031-1033.

(34) (a) Lam, K. S.; Glersaye, S.; Patel, K.; Najmi, S.; Burnham, B. S. Abstracts of Papers, 225th ACS National Meeting, New Orleans, LA, United States, March 23-27, 2003. (b) Krishna, P. R.; Reddy, V. V. R.eddy, Srinivas, R. A new synthetic route to oxazole and pyrrole 2deoxy-C-ribosides. Tetrahedron 2007, 63, 9871-988. (c) Nichols, R.; Andrews, P. C.; Zhang, P.; Bergstrom, D. E. A universal nucleoside for use at ambiguous sites in DNA primers, Nature 1994, 369, 492493. (d) Bergstrom, D. E.; Zhang, P.; Toma, P. H.; Andrews, P. C.; Nichols, R. Synthesis, Structure, and Deoxyribonucleic Acid Sequencing with a Universal Nucleoside: 1-(2'-Deoxy-. $\beta-D-$ ribofuranosyl)-3-nitropyrrole, J. Am. Chem. Soc. 1995, 117, 12011209. (e) Klewer, D. A.; Hoskins, A.; Zhang, P.; Davisson, V. J.; Bergstrom, D. E.; LiWang, A. C. NMR structure of a DNA duplex containing nucleoside analog 1-(2'-deoxy- $\beta$-D-ribofuranosyl)-3nitropyrrole and the structure of the unmodified control, Nucleic Acids Res. 2000, 28, 4514-4522. (f) Harki, D. A.; Graci, J. D.; Korneeva, V. S.; Ghosh, S. K. B.; Hong, Z.; Cameron, C. E.; Peterson, B. R. Synthesis and Antiviral Evaluation of a Mutagenic and Non-Hydrogen Bonding Ribonucleoside Analogue: 1- $\beta-\mathrm{D}$ Ribofuranosyl-3-nitropyrrole, Biochemistry 2002, 41, 9026-9033.

(35) Jacubert, M.; Provot, O.; Peyrat, J. F.; Hamze, A.; Brion, J. D.; Alami, M. p-Toluenesulfonic acid-promoted selective functionalization of unsymmetrical arylalkynes: a regioselective access to various arylketones and heterocycles. Tetrahedron 2010, 66, 3775-3787.

(36) (a) Dong, X.-Y.; Cheng, J.-T.; Zhang, Y.-F.; Li, Z.-L.; Zhan, T.Y.; Chen, J.-J.; Wang, F.-L.; Yang, N.-Y.; Ye, L.; Gu, Q.-S.; Liu, X.Y. Copper-Catalyzed Asymmetric Radical 1, 2-Carboalkynylation of Alkenes with Alkyl Halides and Terminal Alkynes. J. Am. Chem. Soc. 2020, 142, 9501-9509. (b) Zhao, X.; MacMillan, D. W. C. Metallaphotoredox Perfluoroalkylation of Organobromides. J. Am. Chem. Soc. 2020, 142, 19480-9486. (c) Cao, Z.; Li, J.; Sun, Y.; Zhang, H.; Mo, X.; Cao, X.; Zhang, G. Photo-induced coppercatalyzed alkynylation and amination of remote unactivated $\mathrm{C}\left(\mathrm{sp}^{3}\right)-\mathrm{H}$ bonds, Chem.Sci. 2021, 12, 4836-4840.

(37) Representative examples: (a) Sagadevan, A.; Pampana, V. K. K.; Hwang, K. C. Copper Photoredox Catalyzed A3' Coupling of Arylamines, Terminal Alkynes, and Alcohols through a Hydrogen Atom Transfer Process. Angew.Chem. Int. Ed. 2019, 58, 3838-3842. (b) Hazra, A.; Lee, M. T.; Chiu, J. F.; Lalic, G. Photoinduced Copper Catalyzed Coupling of Terminal Alkynes and Alkyl Iodides. Angew. Chem. Int. Ed. 2018, 57, 5492-5496. (c) Sagadevan, A.; Charpe, V. P.; Ragupathi, A.; Hwang, K. C. Visible Light Copper Photoredox-
Catalyzed Aerobic Oxidative Coupling of Phenols and Terminal Alkynes: Regioselective Synthesis of Functionalized Ketones via C $\equiv$ C Triple Bond Cleavage. J. Am. Chem. Soc. 2017, 139, 2896-2899. (d) Sagadevan, A.; Ragupathi, A.; Hwang, K. C. Photoinduced Copper-Catalyzed Regioselective Synthesis of Indoles: Three-Component Coupling of Arylamines, Terminal Alkynes, and Quinones. Angew.Chem. Int. Ed. 2015, 54, 13896-13901. (e) Sagadevan, A.; Ragupathi, A.; Lin, C. C.; Hwu, J. R.; Hwang, K. C. Visible-light initiated copper(i)-catalysed oxidative $\mathrm{C}-\mathrm{N}$ coupling of anilines with terminal alkynes: one-step synthesis of $\alpha$-ketoamides. Green Chem. 2015, 17, 1113-1119. (f) Sagadevan, A.; Hwang, K. C. PhotoInduced Sonogashira C-C Coupling Reaction Catalyzed by Simple Copper(I) Chloride Salt at Room Temperature. Adv. Synth. Catal. 2012, 354, 3421-3427.

(38) (a) Zhang, W.; Wang, F.; McCann, S. D.; Wang, D.; Chen, P.; Stahl, S. S.; Liu, G. Enantioselective cyanation of benzylic C-H bonds via copper-catalyzed radical relay. Science, 2016, 353, 1014-1018. (b) Lu, F.; Liu, D.; Zhu, L.; Lu, L.; Yang, Q.; Zhou, Q.; Wei, Y.; Lan, Y.; Xiao, W. Asymmetric Propargylic Radical Cyanation Enabled by Dual Organophotoredox and Copper Catalysis. J. Am. Chem. Soc. 2019, 141, 6167-6172. (c) Lin, J.-S.; Wang, F.-L.; Dong, X.-Y.; He, W.-W.; Yuan, Y.; Chen, S.; Liu, X.-Y. Catalytic asymmetric radical aminoperfluoroalkylation and aminodifluoromethylation of alkenes to versatile enantioenriched-fluoroalkyl amines. Nat. Commun. 2017, 8, 14841-14851. (d) Cao, Y.-X.; Dong, X.-Y.; Yang, J.; Jiang, S.-P.; Zhou, S.; Li, Z.-L.; Chen, G.-Q.; Liu, X.-Y. A Copper-Catalyzed Sonogashira Coupling Reaction of Diverse Activated Alkyl Halides with Terminal Alkynes Under Ambient Conditions. Adv. Synth.Catal. 2020, 362, 2280-2284.

(39) Selected references for the oxygen oxidation of Ir-photocatalysts, see (a) Condie, A. G.; Gonzalez-Gomez, J. C.; Stephenson, C. R. J. Visible-Light Photoredox Catalysis: Aza-Henry Reactions via C-H Functionalization. J. Am. Chem. Soc. 2010, 132, 1464-1465. Related article on singlet $\mathrm{O}_{2}$ sensitization by Ir photocatalyst, see: (b) Demas, J. N.; Harris, JE. W.; McBride, R. P. Energy Transfer from Luminescent Transition Metal Complexes to Oxygen. J. Am. Chem. Soc. 1977, 99, 3547-3551. (c) Gao, R.; Ho, D. G.; Hernandez, B.; Selke, M.; Murphy, D.; Djurovich, P. I.; Thompson, M. E. Bis-cyclometalated Ir(III) Complexes as Efficient Singlet Oxygen Sensitizers. J. Am. Chem. Soc. 2002, 124, 14828-14829. (d) Huang, C.; Liang, C.; Sadhukhan, T.; Banerjee, S.; Fan, Z.; Li, T.; Zhu, Z.; Zhang, P.; Raghavachari, K.; Huang, H. In-vitro and In-vivo Photocatalytic Cancer Therapy with Biocompatible Iridium(III) Photocatalysts. Angew. Chem. Int. Ed. 2021, 60, 9474-9479. Related article on oxygen oxidation of $\mathrm{Ru}$ photocatalysts, see: (e) Tyson, E. L.; Ament, M. S.; Yoon, T. P. Transition Metal Photoredox Catalysis of Radical Thiol-Ene Reactions. J. Org. Chem. 2013, 78, 2046-2050. (f) Ischay, M. A.; Ament, M. S.; Yoon, T. P. Crossed intermolecular [2 + 2] cycloaddition of styrenes by visible light photocatalysis. Chem. Sci., 2012, 3, 2807-2811. 


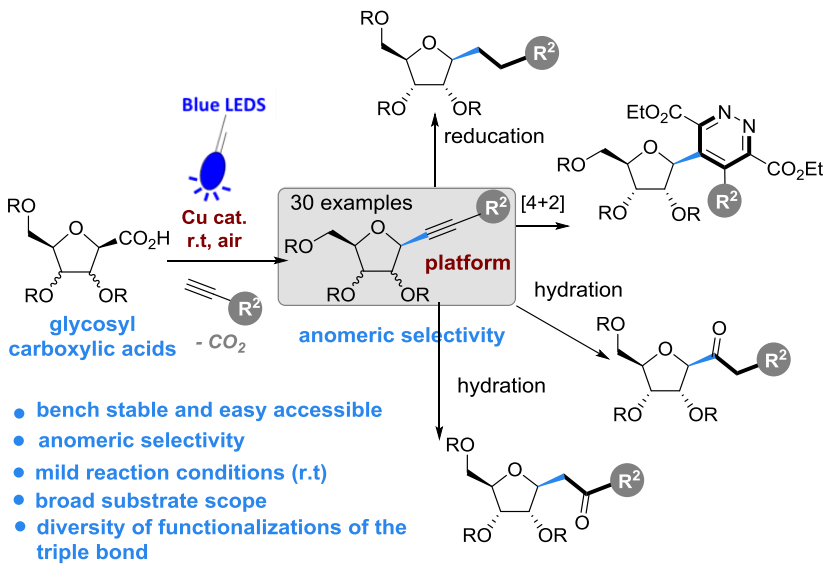

